\title{
Afforestation of Coffee Plantation
}

\author{
Waldênia de M Moura*, Valéria S Cavalcante and Tatiane C Ferreira \\ Agricultural Research Company of Minas Gerais, Brazil.
}

Submission: June 27, 2018; Published: July 27, 2018

"Corresponding author: Waldênia de M Moura, Agricultural Research Company of Minas Gerais/ EPAMIG, Vila Gianetti, 46/47 - Campus of UFV 36570-000, Viçosa, MG, Brazil, Email: waldenia@epamig.ufv.br

\begin{abstract}
Intensive coffee production using a high quantity of inputs promotes several impacts to the environment. As an alternative, the afforestation of coffee plantations is a practice that contributes to the sustainability of production, since it contributes to the improvement of soil characteristics and to the reduction of pest and disease incidence, providing less use of chemical fertilizers and agrochemicals. Thus, this review has the objective to present the main characteristics and effects of the tree plantations of coffee in the production and quality of the beverage. Wooded coffee plantations may use one or more tree species that influence biodiversity, and the more distinct are the plants used for the highest shading is biological diversity. The choice of species for shading and management of these influence the productivity of coffee, because these plants store differently biochemicals and nutrients that will be returned to the soil by pruning equipment being decomposed by microorganisms. The shading influences coffee beverage by providing variation in beverage quality and major biochemicals (caffeine, trigonelin, chlorogenic acids, lipids and sucrose). Therefore, despite the benefits of afforestation coffee to the environment, the results in the literature regarding the increase of productivity and drink quality are still controversial, being appropriate the proper management of the plantations, since these characteristics vary with the degree of shade provided by arboreal species, the edaphoclimatic conditions, the species and the coffee genotypes used.
\end{abstract}

Keywords: Coffea arabica; Shading cultivation; Productivity; Beverage quality

\section{Introduction}

The coffee originates from the African equatorial forest, cultivated in shade, however, it is currently cultivated in several countries of the world predominantly in full sun. It is a product which is considered a high-value commodity in the international market, Brazil is the largest exporter and producer worldwide [1]. Coffee cultivation also has great social importance, since it is commonly concentrated in small farms, from the planting to the commercialization, involving many people [2]. To obtain high productivity coffee uses up large amounts of inputs that cause different damage to the environment. In this way, more sustainable managements of cultivation have been gaining space in the international and national market being highlighted the afforestation plantations that use tree species for the shade of the coffee, being considered one of the practices of ago-ecological base, therefore, they aim at the minimum the use of agricultural technologies, as well as reducing the application of pesticides and chemical fertilizers, contributing to the reduction of environmental contamination, which directly or indirectly influences the health of coffee growers and consumers $[3,4]$. Thus, this review has the objective to present the main characteristics and effects of the afforestation plantations on the grain production and the coffee beverage quality.

\section{Importance of Cultivation Coffee Afforestation}

The management of agricultural areas is one of the human activities that have most impact on the environment, which is be coming increasingly important on the world scenario. After the green revolution, there was an intensive use of natural resources, promoting, over time, a decrease in the supply of fossil fuels, fresh water, phosphorus and other resources [5]. This fact has been reflected in changes in agriculture, in this way ago-ecological based systems have emerged that encompass practices that aim at the minimal use of modern agricultural science technology, such as: elevated fields, terraces, polycultures, agroforestry systems, among others [4]. Among these practices that have the objective of greater sustainability of the environment, the cultivation of afforestation coffee refers to the system in which coffee is cultivated intercropped with trees of shade, being able to be used fruit or forest. Thus, for the installation of these plantations, it is necessary to have a comprehensive knowledge of the management practices to be adopted and may be intensive systems where the shade cover is provided by a single canopy layer, which is usually composed of few or even a single species promoting less biodiversity. While in less intensive crops there is usually a multiple layer canopy due to the use of mixtures of tree species with different ages, favoring high biological diversity [6]. The species of plants used for afforestation have an impact on the yield of coffee cultivation, since they create a microclimate that interferes throughout the environment. Influencing the diversity of pollinators, diseases, pests, microfauna, macrofauna, among others. In this sense, the use of inappropriate species for shading contributes to the need for further intensification 
of agriculture, besides the reduction of the pest and disease [7]. This is relevant mainly for the afforestation Coffea arabica crops, since this species is more susceptible to pests and diseases in relation to Coffea canephora [8]. The rust (Hemileia vastatrix), the main disease of the coffee tree, may present a higher incidence and severity in the system of cultivation in full sun when the productivity is higher, than in the woody crops when the yield is lower. However, over the years this trade-off may disappear, since afforestation has the capacity to stabilize coffee production [9]. Shade trees retain a large amount of nutrients from the soil that return to the soil by means of pruning, which must be carried out regularly [10].

The return of this material to the soil, provides the greater activity of decomposing microorganisms, increasing the release of nutrients and improving soil structure, reducing the risks of erosion, as well as contributing to improvements in chemical, physical and soil organic matter [11-13].

Impact of the Afforestation System on Productivity and Quality of the Beverage

The afforestation of coffee plantations causes great concern to coffee growers due to the possibility of a decrease in production due to light competition between plants [14]. However, with adequate shading of crops, greater or similar production of coffee beans can be obtained in relation to planting in full sun [15], due to the higher levels of $\mathrm{C}$ and $\mathrm{N}$ in the soil, as observed in the consortium between coffee and banana plantations, where there was a reduction in the need for nitrogen fertilizers and less change in soil acidity [13]. In the world coffee trade, the quality of the beverage determined by the cup test is the main standard of evaluation, and not always a good flavor is associated with uniform grain size and good appearance, in this sense the shading of the crops can provide increase of positive attributes (preference and appearance), along with the decrease of negative attributes (astringency and bitterness) The major biochemical compounds present in the coffee beverage are also influenced by the afforestation of coffee plants, providing an improvement in caffeine content when the shade is increased to $30 \%, 50 \%, 70 \%$ and $80 \%, 30 \%, 50 \%$ and $80 \%$ reduction of trigonelin in shading levels, with an increase of this compound only at the shade level of $70 \%$; lower amount of chlorogenic acids and high lipid content in coffee beans with increasing shade level. It is emphasized that the response of coffee species and genotypes to beverage quality is different with shading, and further research is needed to verify their adaptability in this condition [16]. Moreover, in the literature there are also studies of the effect of trees in decreased productivity and quality of the beverage, as evidenced by [17] which found a higher yield and improved quality of the coffee under trees drink, but only increase the size of the grains, so they report that it would not economically compensate the coffee grower for the implantation of the system. Likewise [18] observed a similar result, in addition to a lower amount of sucrose in the grains produced, suggesting a redirection of sucrose metabolism in other ways. About production costs, in in the growing of coffee afforested monetary costs may be lower compared to full sun, due to the management of plantations to sustainable practices without necessarily having higher expenses for the grower. It should be emphasized that this system of cultivation does not result in higher costs, since the management of the canopy of shade plants can be carried out along with the operations applied to the coffee tree, and in small properties by the family members. Added to this, that in fruit cases the fruits can be used for own consumption or as a source of extra income [19].

\section{Conclusion}

The coffee tree plantations provide a microclimate that influence the incidence of pests and diseases in coffee plantations, and improvements in the physical, chemical and organic attributes of the soil, promoting a reduction in the use of chemical inputs and consequently increasing the sustainability of the system. Regarding the productivity and quality of the beverage, there are controversies regarding the possible benefits of this cultivation system, since the crop response varies with the management adopted, as well as with the edaphoclimatic condition of each place and in relation to the coffee genotypes used.

\section{Conflict of Interest}

The authors explicitly declare no conflicts of interest.

\section{References}

1. Batista LR, Souza SC, Batista CS, Schwan RF (2016) Coffee: types and production. Encyclopedia of Food and Health 244-251.

2. Damatta FM, Ronchi CP, Maestri M, Barros RS (2007) Ecophysiology of coffee growth and production. Brazilian Journal of Plant Physiology (19)4: 485-510.

3. Millard E (2017) Still brewing: Fostering sustainable coffee production. World Development Perspectives 7(8): 32-42.

4. Altieri MA, Funes Monzote FR, Petersen P (2012) Agroecologically efficient agricultural systems for smallholder farmers: contributions to food sovereignty. Agronomy for Sustainable Development 32(1): 1-13.

5. Francis CA, Wezel A (2015) Agroecology and Agricultural Change. International Encyclopedia of the Social \& Behavioral Sciences 1: 484487.

6. Boreux V, Vaast P, Madappa LP, Cheppudira KG, Garcia C, et al. (2016) Agroforestry coffee production increased by native shade trees, irrigation, and liming. Agronomy for Sustainable Development 36(3): 1-9.

7. Nesper M, Kueffer C, Krishnan S, Kushalappa CG, Ghazoul J (2017) Shade tree diversity enhances coffee production and quality in agroforestry systems in the Western Ghats. Agric Ecosyst Environ 247(1): 172-181.

8. Vandermeer J, Perfecto I, Philpott S (2010) Ecological complexity and pest control in organic coffee production: uncovering an autonomous ecosystem service. Bioscience 60(7): 527-537.

9. López Bravo DF, Virginio Filho EDM, Avelino J (2012) Shade is conducive to coffee rust as compared to full sun exposure under standardized fruit load conditions. Crop Protection 38: 21-29.

10. Tully KL, Lawrence D (2011) Closing the loop: nutrient balances in organic and conventional coffee agroforests. J Sustain Agric Environ 35(6): 671-695. 
11. Tully KL, Lawrence D, Wood SA (2013) Organically managed coffee agroforests have larger soil phosphorus but smaller soil nitrogen pools than conventionally managed agroforests. Biogeochemistry 115(1-3): 385-397.

12. Bagyaraj DJ, Thilagar G, Ravisha C, Kushalappa CG, Krishnamurthy $\mathrm{KN}$, et al. (2015) Below ground microbial diversity as influenced by coffee agroforestry systems in the Western Ghats, India. Agric Ecosyst Environ 202: 198-202.

13. Cerda R, Allinne C, Gary C, Tixier P, Harvey CA, et al. (2017) Effects of shade, altitude and management on multiple ecosystem services in coffee agroecosystems. Eur J Agron 82: 308-319.

14. Lima PC, Moura WM, Volpato MML, Reigado FR, Santos J (2010) Arborization of coffee plantations in Brazil. In: Reis PR, Cunha RL (Editors.), Arabica coffee from planting to harvest. (1st Edition), EPAMIG, Minas Gerais, Viçosa, Brazil, pp. 863-895.

This work is licensed under Creative

Commons Attribution 4.0 License
15. Haggar J, Barrios M, Bolaños M, Merlo M, Moraga P, et al. (2011) Coffee agroecosystem performance under full sun, shade, conventional and organic management regimes in Central America. Agroforestry Systems 82(3): 285-301.

16. Cheng B, Furtado A, Smyth HE, Henry RJ (2016) Influence of genotype and environment on coffee quality. Trends Food Sci Technol 57: 20-30.

17. Steiman S, Idol T, Bittenbender HC, Gautz L (2011) Shade coffee in Hawai 'I-Exploring some aspects of quality, growth, yield, and nutrition. Sci Horticult 128(2): 1249-1259.

18. Geromel C, Ferreira LP, Davrieux F, Guyot B, Ribeyre F, et al. (2008) Effects of shade on the development and sugar metabolism of coffee (Coffea arabica L.) fruits. Plant Physiol Biochem 46(5): 569-579.

19. Meylan L, Gary C, Allinne C, Ortiz J, Jackson L, et al. (2017) Evaluating the effect of shade trees on provision of ecosystem services in intensively managed coffee plantations. Agric Ecosyst Environ 245: 32-42.

\section{Your next submission with Juniper Publishers will reach you the below assets}

- Quality Editorial service

- Swift Peer Review

- Reprints availability

- E-prints Service

- Manuscript Podcast for convenient understanding

- Global attainment for your research

- Manuscript accessibility in different formats

(Pdf, E-pub, Full Text, Audio)

- Unceasing customer service

Track the below URL for one-step submission https://juniperpublishers.com/online-submission.php 